\title{
Microbiology Susceptibility Measurement, Test or Examination Detail
}

National Cancer Institute

\section{Source}

National Cancer Institute. Microbiology Susceptibility Measurement, Test or Examination

Detail. NCI Thesaurus. Code C162146.

Further description of a microbiology susceptibility test or microbiology susceptibility test code. 